\title{
The place behind the case: leptospirosis risks and associated environmental conditions in a flood-related outbreak in Rio de Janeiro
}

\author{
O lugar do caso: leptospirose e riscos associados \\ a condições ambientais durante o surto de 1996 \\ na Zona Oeste do Rio de Janeiro
}

Christovam Barcellos 1

Paulo Chagastelles Sabroza 2

\footnotetext{
1 Departamento de Informações em Saúde, Centro de Informação Científica e Tecnológica, Fundação Oswaldo Cruz. Av. Brasil 4365, Rio de Janeiro, $R J$ 21045-900, Brasil. xris@fiocruz.br 2 Departamento de Doenças Endêmicas Samuel Pessoa, Escola Nacional de Saúde Pública, Fundação Oswaldo Cruz. Rua Leopoldo Bulhões 1480, térreo, Rio de Janeiro, $R J$ 21041-210, Brasil.
}

\begin{abstract}
The environmental context in which a leptospirosis outbreak took place during the summer of 1996 in the Rio de Janeiro Western Region was examined by using spatial analysis of leptospirosis cases merged with socio-demographic data using Geographic Information System (GIS). Risk areas were mapped based on flood and solid waste accumulation information for the region. Incidence rates were calculated for each area by the division of number of cases per total population in the specific areas. Higher rates were observed for census tracts inside the flood risk area and in the vicinities of waste accumulation sites. These findings are in agreement with the expected risk of leptospirosis, evidencing the role of environmental and collective factors in the determination of the disease.
\end{abstract}

Key words Leptospirosis; Spatial Analysis; Geographical Information Systems; Disease Outbreaks; Sanitation

Resumo Neste trabalho foi averiguado o contexto ambiental do surto de leptospirose ocorrido no verão de 1996, na Zona Oeste do Rio de Janeiro, utilizando-se o Sistema de Informações Geográficas (SIG). As áreas de risco foram estabelecidas segundo o mapeamento das regiões sujeitas à inundação e de zonas em que há acumulação de lixo doméstico. Foram calculadas taxas de incidência da doença pela razão entre o número de casos e a população total em cada uma dessas áreas. Maiores taxas de incidência foram verificadas dentro da região sujeita à inundação e em torno daquelas de acumulação de lixo. Os resultados evidenciam o papel de fatores de risco ambientais e coletivos na determinação da doença.

Palavras-chave Leptospirose; Análise Espacial; Sistemas de Informação Geográfica; Surtos de Doenças; Saneamento 


\section{Introduction}

Identification of risk areas and disease clusters is a painstaking but indispensable task for environmental epidemiology. However, environmental sources of risk and high disease incidence areas are rarely coincident in space. For instance, human poisoning may occur far from pollution sources depending on the sort of environmental and social processes that disperse or concentrate pollutants and intensify the exposure of specific population groups (Briggs, 1992; Sexton et al., 1992). Spatial analysis may help explain disease risks by integrating social, environmental, and demographic data (Kolsky \& Blumenthal, 1995). One flaw in epidemiology's theoretical framework is the often poorly used geographic approach, failing to account for the extension of space to be considered in analyzing health events. Discrete division of space according to administrative or physical boundaries is an important step to the estimation of epidemiological indicators and makes possible the linkage between environment and health data (Nurminen, 1995; Croner et al., 1996). The relationship between sanitation conditions and health outcome has been studied through the type of methodologies that consider interactions between individuals and their environment, although water-related diseases could be better described as a combination of social, environmental, and educational conditions (Gesler et al., 1997; Heller, 1997).

During February 1996 there was heavy rainfall all over Rio de Janeiro, causing persistent flooding in several areas of the city. Hundreds of leptospirosis cases were reported during the subsequent weeks, accounting for the largest epidemics in the city's history. These cases mainly concentrated in the city's western and southern lowlands. Leptospirosis is an acute disease commonly affecting the liver and kidneys. Rats (mainly Rattus norvegicus) and dogs are important urban reservoirs for leptospirosis (Lacaz et al., 1972). Human infection results from cutaneous or oral contact with the leptospira, during which contaminated water and animal excrement play an important role (Katz et al., 1991). Case fatality can reach $20 \%$ if cases are not promptly diagnosed and treated (Benenson, 1997). Leptospirosis is an endemic disease in the city of Rio de Janeiro, presenting a baseline incidence of 30 to 50 cases per year, i.e., around 1 case per 100,000 inhabitants (SMS, 1997) and sporadic disease outbreaks, mainly after floods (Lacaz et al., 1972), due to the high prevalence of infection in rodents as verified in city slums (Pereira \& Andrade, 1988). The dis- ease event thus refers back to a sequence of environmental conditions involving solid waste accumulation, proliferation of rodents, and vulnerability to floods, all of which are avoidable or controllable through public health promotion and sanitation policies.

A previous study examined the socio-environmental determinants of leptospirosis, identifying conditions characterizing sectors near the location of cases (Barcellos \& Sabroza, 2000). Poor sanitation conditions and flood risk were identified as the main variables or determinants distinguishing areas with leptospirosis cases. In the current article, on the contrary, we analyze the spatial distribution of leptospirosis cases according to the location of these environmental risk factors. We then propose a model for the disease's endemic and epidemic dynamics.

\section{Methodology}

The total population of Rio de Janeiro's western region according to the 1996 census (IBGE, 2000), was 275,000 inhabitants. Population distribution in the region (Figure 1) shows two main urban nuclei: Santa Cruz and Sepetiba. Peripheral areas in this part of the city display a low population density, with values similar to those of rural areas. A considerable portion of the area has been preserved due to the presence of mountainous areas (north and east), military grounds (south), and industrial complexes (west), thereby hindering urban sprawl in the region as a whole. Slum areas are mainly located in northern Santa Cruz, along the railroad tracks and highways, where availability of land and transportation favors occupation. The slum population is 19,000 , or some $7 \%$ of the region's total population. The population grew more from 1991 to 1996 in the peripheral as compared to urban areas. In the southern area, the presence of marshes, mangroves, and military grounds has discouraged new urban settlement.

Geographic Information System (GIS) was used to gather and analyze socio-environmental and epidemiological data, constituting specific information layers in the system. Leptospirosis cases were diagnosed clinically, reported, and investigated by the local health authority. A sample of some $30 \%$ of suspected cases was submitted to serologic microscopic agglutination test. The prevailing serovar of cases occurring after the flood was Leptospira interrogans (Ko et al., 1999), although a gamut of other serovar may be found under other conditions, mainly during non-epidemic periods (Al- 
Figure 1

Population distribution and main roads in the Rio de Janeiro western region.
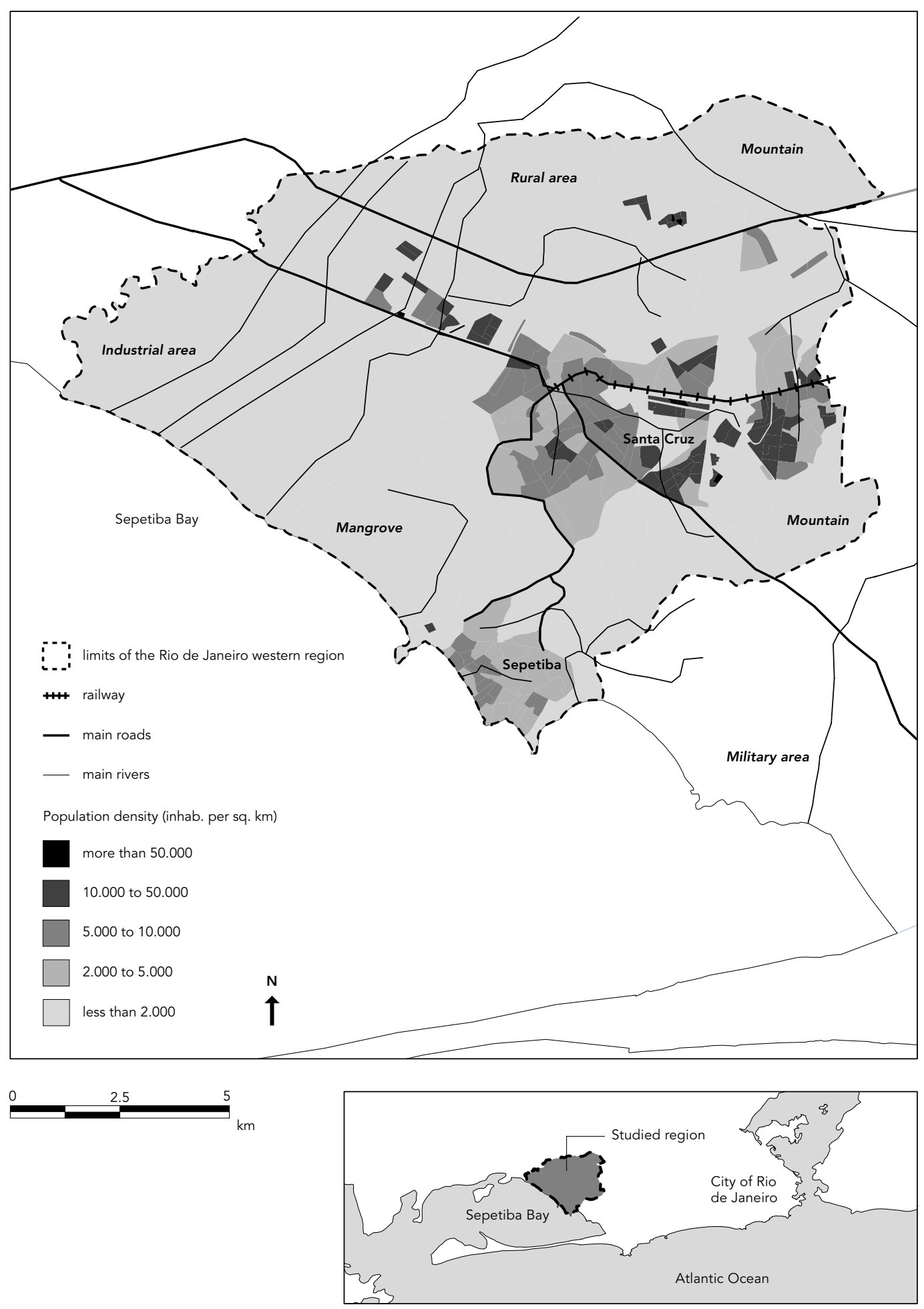
meida et al., 1994). A total of 87 leptospirosis cases were located in the western region between the 8 th and 14 th epidemiological weeks of 1996. This period corresponds to 10 to 54 days after the heavy rainfall starting on February 13. Coordinates for reported case residences were obtained by interpolation of street segments. This procedure allowed for the location of 73 residences.

Flood risk areas constitute a second information layer, obtained by digitizing polygons in which low terrain slope and rain water convergence increase flood occurrence probability (IPLANRIO, 1995). These spatial data were disposed on and merged to the basis of the 276 census tract (CT) polygons. Census data for 1991 and 1996 were obtained from the Brazilian Census Bureau (IBGE, 2000) and associated with CT polygons using a common code.

Solid waste accumulation is an important factor for urban rodent feeding and sheltering strategies. Due to the absence of reliable data on rodent distribution in the city, waste accumulation was used as an indicator of probable rat presence in the region. Accumulated solid waste was calculated for each CT, based on existing data on population, area, and solid waste collection, according to the following equation:

$$
P a=\frac{365 \cdot L \cdot P o p(1-C o l)}{1000 \cdot \text { Area }}
$$

Where:

$P a=$ Annual net solid waste load (in ton. $\mathrm{km}^{-2}$.year-1);

$L=$ Municipal solid waste production per capita (in kg.inhab-1. day $^{-1}$ );

Pop = Total CT population;

$\mathrm{Col}=$ Percentage of residences whose solid waste is collected;

Area $=$ CT area $\left(\right.$ in $\left.\mathrm{km}^{2}\right)$.

High net waste load values may lead to both waste accumulation in dumps and the proliferation of disease vectors. The indicator is a direct function of demographic density, as can be deduced from the equation. Solid waste production by CT was estimated based on CT population and a mean per capita waste production of 0.6 kg.inhab-1. day-1 (Phillipi Jr., 1980). Net waste load was obtained by subtracting the percentage of collected waste from gross waste production.

These data were gathered by the overlay of different layers containing relevant information for this study: CT, represented by polygons associated with socio-demographic data; flood areas, represented by polygons; and points representing leptospirosis case residences.
Sectors presenting a waste accumulation rate greater than 10 ton. $\mathrm{km}^{2}$.year-1 or inside flooded areas were considered risk areas for leptospirosis. Population and cases contained in each of these risk areas were calculated using layer overlay techniques, as a GIS function (Vine et al., 1997). Incidence rates, as number of cases per 100,000 inhabitants, were calculated based on these estimates.

\section{Results and discussion}

Temporal evolution of leptospirosis cases in the Rio de Janeiro western region is shown in Figure 2. The number of leptospirosis cases before and after the outbreak is slight. A typical common-source epidemic pattern can be observed, with increasing case numbers from the 3 rd to the 5 th week after the flood (9th to 11 th epidemiological week, respectively).

Most households in the urban area are served by regular municipal waste collection. Population density often imposes restrictions on the delivery of this service, which is virtually absent in rural areas. Furthermore, waste collection suffers severe restrictions in slums. Urban areas in Santa Cruz and Sepetiba are actually covered by regular waste collection. Peripheral and mountainous areas present difficulties in accessing sanitation services, aggravated by the poor-quality water supply and lack of sewage disposal. Sectors where waste is likely to accumulate are situated on the periphery of the large urban centers. Rural and industrial areas located in the eastern mountainous and western lowland tracts, respectively, present lower waste accumulation and probably a lower rat population due to the low population density. Meanwhile, urban centers (Sepetiba and Santa Cruz) present a high proportion of solid waste collection, avoiding solid waste accumulation, despite the high population density in these tracts.

Areas at risk of flooding occupy a large central portion of the region, as shown in Figure 3, covering mainly the middle stretches of local rivers. These rivers drain the Pedra Branca mountain, and water outflow may be hampered in the lower-altitude stretches. Sediment accumulation and high tides in the river estuaries are identified as factors contributing to the increased probability of floods in the Sepetiba Basin (Argento et al., 1995).

Geo-referencing of leptospirosis cases (Figure 3) allowed the identification of areas with a high case density on a local scale. Deriving from the maps, one observes the concentration of 
cases on the outskirts of Sepetiba and Santa Cruz, where concentration of human and vector populations together with land vulnerability to floods form a scenario of susceptibility to leptospirosis outbreaks. Cases are virtually absent in the hilly and rural areas, characterized by low population density, steep terrain, and insufficient coverage of sanitation services.

Table 1 shows the different leptospirosis incidence rates calculated for census tracts according to the boundaries of flood risk areas. Leptospirosis case numbers are compared inside and outside the flood risk areas. Tracts situated outside the flood risk areas are indeed more populous. The incidence rate in these areas is twice that observed outside. This difference is statistically significant according to a chisquare test considering a Poisson distribution.

Table 2 shows the calculated incidence rates for different distance ranges around waste accumulation sites. Table 2 shows the high leptospirosis incidence rates surrounding waste

\section{Figure 2}

Weekly distribution of leptospirosis cases in the Rio de Janeiro western region after intensive rainfall during the 4th epidemiological week.

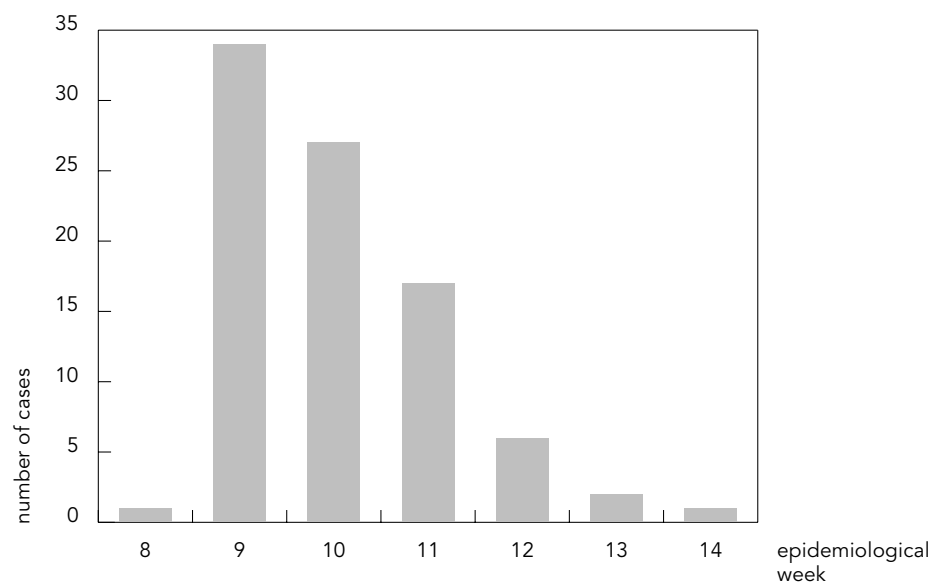

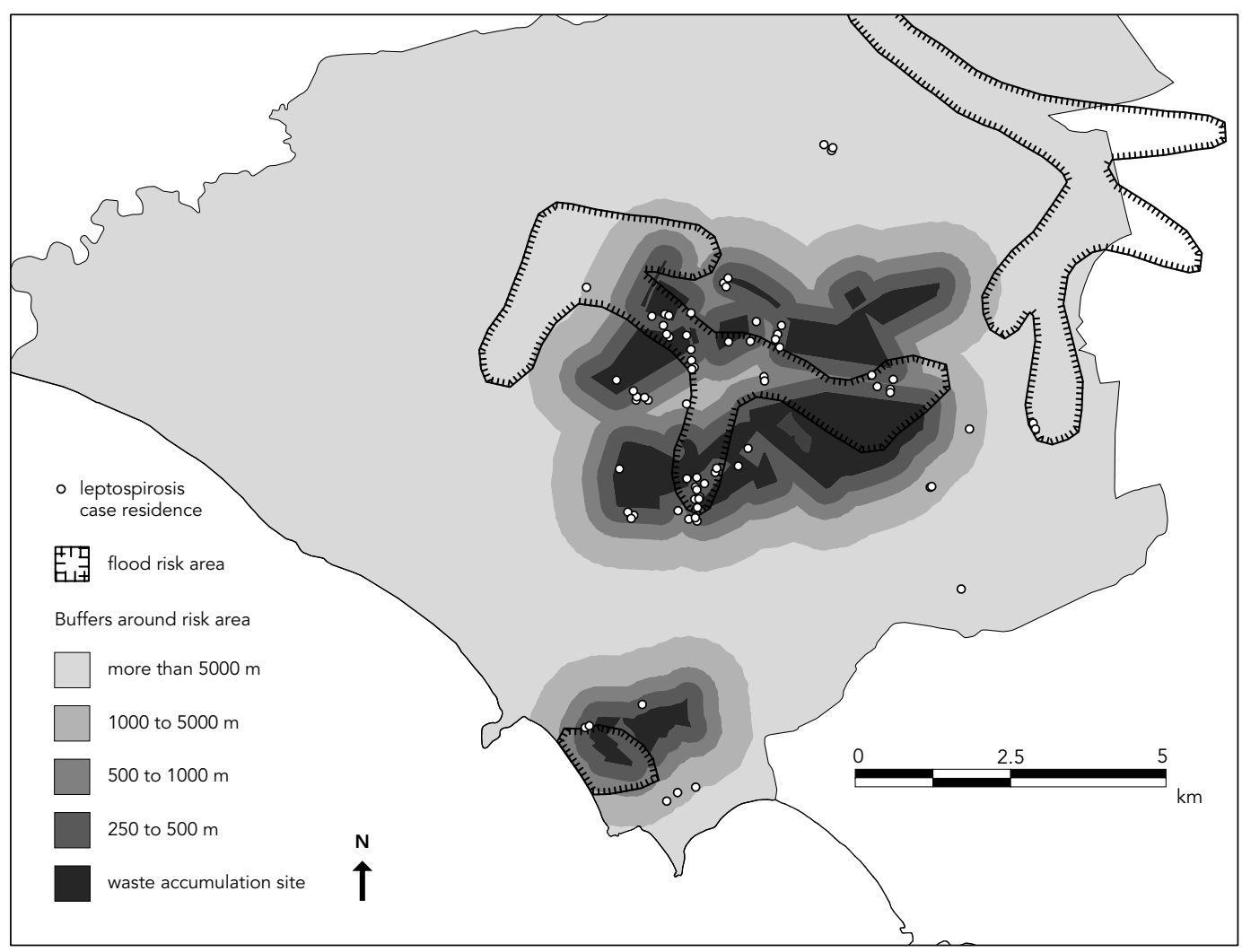


Table 1

Population, number of cases, and incidence rate in and outside the flood risk area.

\begin{tabular}{lccc}
\hline & Population & $\begin{array}{l}\text { Leptospirosis } \\
\text { cases }\end{array}$ & $\begin{array}{l}\text { Incidence } \\
\text { rate* }\end{array}$ \\
\hline Inside flood risk area & 83241 & 35 & 42.05 \\
Outside flood risk area & 192407 & 38 & 19.75 \\
Total & 275648 & 73 & 26.48 \\
\hline
\end{tabular}

* statistically different according to chi-square test.

Table 2

Population, number of cases, and incidence rate according to the distance from waste accumulation sites.

\begin{tabular}{lccc}
\hline Distance from foci $(\mathrm{m})$ & Population & $\begin{array}{l}\text { Leptospirosis } \\
\text { cases }\end{array}$ & $\begin{array}{l}\text { Incidence } \\
\text { rate }\end{array}$ \\
\hline Less than 250 & 49003 & 11 & 22.45 \\
$250-500$ & 51092 & 40 & $78.29 \mathrm{a}$ \\
$500-1000$ & 35364 & 8 & 22.62 \\
$1000-5000$ & 36337 & 8 & 22.02 \\
More than 5000 & 103852 & 6 & $5.78 \mathrm{~b}$ \\
Total & 275648 & 73 & 26.48 \\
\hline
\end{tabular}

a statistically higher than the mean value according to chi-square test.

b statistically lower than the mean value according to chi-square test.

accumulation sites. For distances greater than $1,000 \mathrm{~m}$ from these sites, incidence rates decrease towards values comparable to endemic periods. The highest rate is observed not at the core of waste accumulation sites, but surrounding these sites (at a distance of 250 to $500 \mathrm{~m}$ ). This difference is statistically significant according to a chi-square test considering a Poisson distribution of cases. Surprisingly, based on the map (Figure 3), most cases occurred in areas that do not present waste accumulation problems. On the contrary, critical areas, where suspected disease foci are located, contain a negligible number of cases.

A combination solid waste accumulation and flood conditions is the most appropriate theoretical explanation for leptospirosis. Incidence rates for each class of combined situations for these risk areas are shown in Figure 4.

Observed incidence rates decrease with the distance from waste accumulation sites. Higher incidence rates are observed for census tracts inside flood risk areas for all distance ranges from waste accumulation sites. However, the combined effect of waste accumulation and flooding is more intense in the vicinity of the suspected foci. The lowest incidence rate is observed for census tracts outside flood risk areas and far from waste accumulation sites. When compared to these tracts, higher risk areas show a tenfold incidence rate.

The outbreak mainly affected the population residing close to waste accumulation sites. However, residents of census tracts outside flood risk areas were protected from the disease. The spatial gap observed between disease clusters and environmental risk factors can be explained by immunological, geographic, and exposure characteristics. First, leptospirosis cases under flood conditions can occur far from the suspected foci due to individual immunological protection in inhabitants of these foci. People living at distances greater than $1000 \mathrm{~m}$ from foci are probably protected against rodents and the infectious agent due to the limited dispersion capacity during the flood. Conversely, people living close to risk areas are expected to have had contact with the infectious agent prior to the flood, thus acquiring immunity due to the proximity of suspected foci (Pavlowsky, 1988). In this sense, slums can be considered endemic areas for leptospirosis, yet displaying low incidence rates during the outbreak. A survey performed in one of the lowland Rio de Janeiro slums demonstrated a human serological prevalence as high as $25 \%$, with an infection rate of $1 \%$ per year (Pereira \& Andrade, 1990). In such cases, infection is found to be related to occupational and behavioral factors, presenting a typically endemic evolutionary pattern (Velazquez et al., 1984).

Second, the range between risk factors and location of case residence may be an artifact produced by errors involved in the location of geographic features in GIS. This is probably a refutable reason, due to the technical features of GIS. The average CT area is $0.28 \mathrm{~km}^{2}$, with an average radius of $210 \mathrm{~m}$. The location error of GPS equipment (Global Position System, a satellite-based coordinate acquirer) is between 20 and $40 \mathrm{~m}$. The average length of street segments is $150 \mathrm{~m}$. As the reported case residences were located by interpolation in street segments, a maximum error of $75 \mathrm{~m}$ is expected for coordinates of the recording position. These distances are considerably greater than the linear resolution of the CT base map, which has an expected error of $2.5 \mathrm{~m}$. Values are related to the scale on which the cartographic base was constructed. Each working scale induces a resolution limit that affects the statistical results 
obtained from the map. In this study, the distance at which poor sanitation services influence location of leptospirosis cases is considerably greater than the pertinent geo-referencing errors.

Finally, contact between the infectious agent and susceptible individuals can occur distant from the supposed foci or the case residence because of rodent and human circulation, especially during floods. As mentioned before, the 1996 summer flood persisted for several days, and people may have been exposed to contaminated floodwater and mud on their way to work and shopping, although living in a well-served and non-inundated area. Unfortunately, GIS often works with a static representation of geographic entities, although space is composed of a system of objects and actions (Santos, 1996).

A disease production model for flood situations is summarized in Figure 5. During dry periods, high leptospira concentrations in the soil are limited to a few meters around waste accumulation sources. During floods, the infectious agent spreads and reaches distant areas under the impact of water. This same flood dilutes both the agent and also its infectivity at great distances from the source. This dispersion promotes the agent's contact with population groups, i.e., individuals with no previous contact with the bacteria. Individuals living close to foci are believed to have more frequent contact with the agent, given the higher prevalence of infection there. Thus, a shift in seropositivity can be predicted in flood situations. Some infected individuals (approximately 30\%) may develop the disease, depending not only on individual immunological conditions, but also the exposure route and dose (Benenson, 1997).

\section{Final comments}

Leptospirosis cases result from a combination of negative social and environmental conditions. This same environment is also the stage for collective health measures such as sanitation practices. In the case of Rio de Janeiro's western region, high incidence rates were identified in areas that had precarious sanitation conditions and were vulnerable to floods. This relationship is not direct, nor does one observe the exact location where environmental risks are concentrated. Densely populated urban areas displayed an excess of leptospirosis cases around waste accumulation sites. Rural and mountainous areas and those with sewage and waste collection services are protected against

\section{Figure 4}

Leptospirosis incidence rate according to distance from suspected foci and flood areas in the Rio de Janeiro western region, in cases per 100,000 inhabitants.

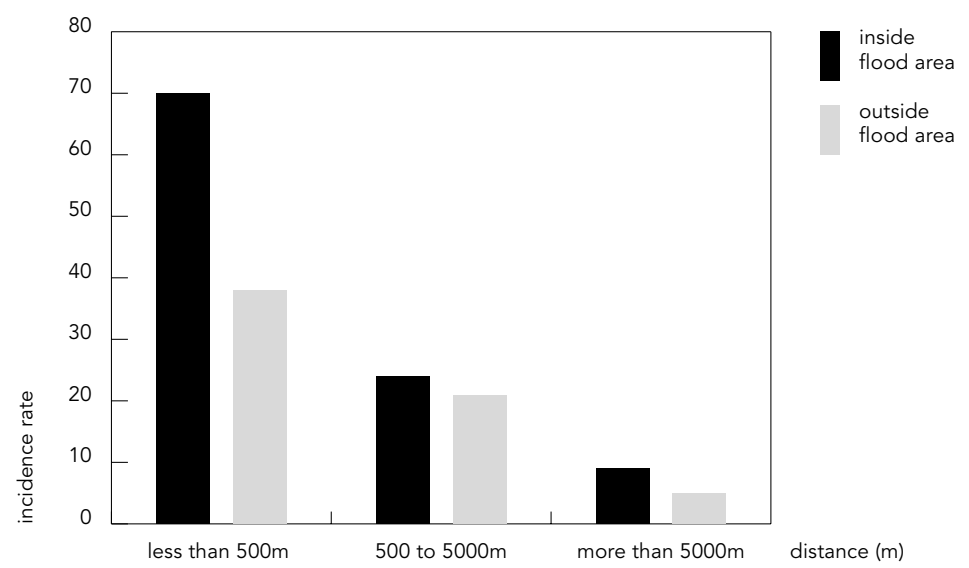

Figure 5

Conceptual model of leptospirosis spread during flood situations.

Variation of risk indicators as a function of distance to solid waste source.
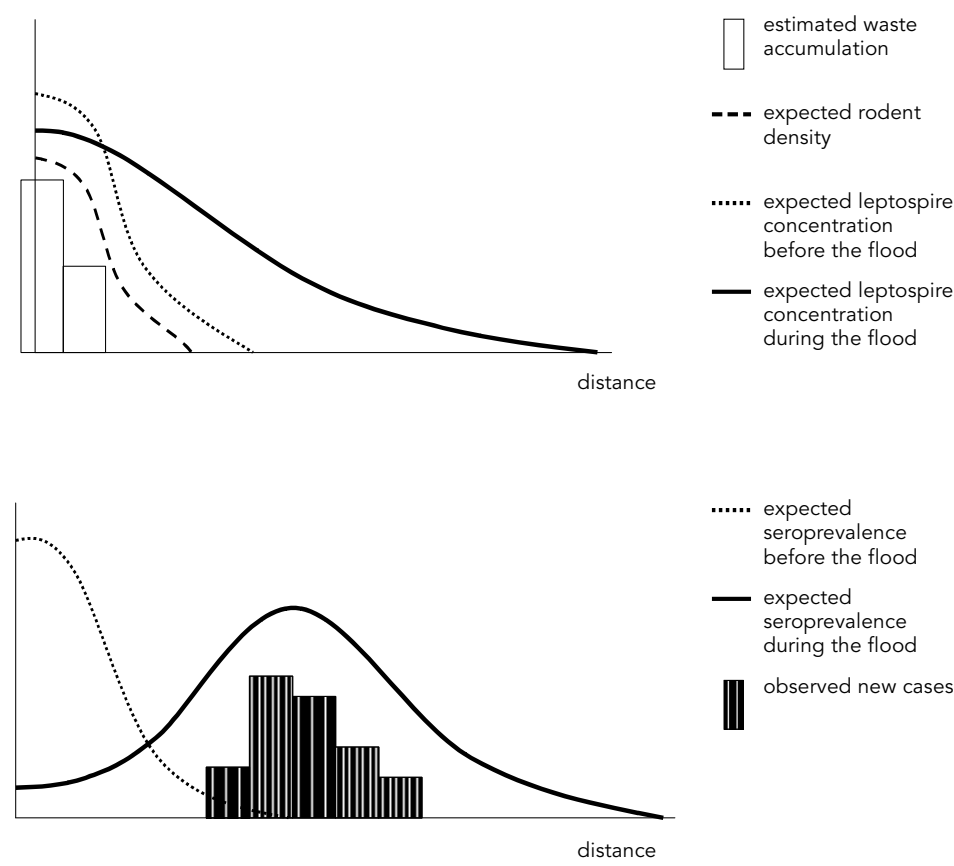
the proliferation of rodents and pathogenic microorganisms. Urbanization thus plays a double role of promoting education and sanitation, but increasing interactions of infectious agents and the population by overcrowding and pollution (Williams, 1990).

Exposure to infectious agents is an environmental and therefore collective process. The environmental conditions fostering diseases are impossible to retrieve through the aggregation of individual data, but may more likely be obtained from bases other than strictly epidemiological data (Vine et al., 1997; Diez-Roux, 1998). Individual response to environmental exposure is complementary and may diverge from collective data. For instance, most of the investigated cases deny contact with solid waste, despite living near areas with deficient municipal waste collection. Such areas are latent disease foci, and even when a residence displays appropriate waste collection and disposal practices, local infestation by rodents can increase risks due to the presence of solid waste dumps in the neighborhoods. One of the important issues raised by this study relates to establishing the physical-territorial limits of these surroundings, which can be influenced by solid waste, rodent, and bacterial factors. These events and risk situations are not coincident in time and space. We propose several workable risk indicators for the steps by which disease is processed: solid waste accumulation; rat infestation; environmental contamination by bacteria; leptospirosis seroprevalence; and clinical cases themselves. These events are linked by a chain of actions that occur in space but are probably lagged in time and space. It is thus difficult to establish a direct and linear relationship between environmental risk and disease cluster.

\section{Acknowledgments}

Epidemiological data were kindly provided by the Rio de Janeiro State Health Secretariat. Other field and cartographic information was gathered by Simone M. dos Santos and Maria de Fátima Pina. The authors wish to thank the useful collaboration of Celia Leitão Ramos on the paper review. This research was supported by the National Research Council (CNPq). 


\section{References}

ALMEIDA, L. P.; MARTINS, L. F.; BROD, C. S. \& GERMANO, P. M., 1994. Seroepidemiologic survey of leptospirosis among environmental sanitation workers in an urban locality in the southern region of Brazil. Revista de Saúde Pública, 28:76-81.

ARGENTO, M. S.; CARVALHO Jr., W.; CRUZ, C. B. M. \& MAYR, L. M., 1995. Impactos ambientais de grandes empreendimentos: O caso de Sepetiba. In: IV Congresso Brasileiro de Defesa do Meio Ambiente, Anais, pp. 323-333, Rio de Janeiro: Editora da Universidade Federal do Rio de Janeiro.

BARCELLOS, C. \& SABROZA, P. C., 2000. Socio-environmental determinants of the leptospirosis outbreak of 1996 in western Rio de Janeiro: A geographic approach. International Journal of Environmental Health Research.

BENENSON, A. S., 1997. Manual para el Control de las Enfermedades Transmisibles. Washington, D.C.: Organización Panamericana de la Salud.

BRIGGS, D. J., 1992. Mapping environmental exposure. In: Geographic and Environmental Epidemiology: Methods for Small-Area Studies (P. Elliot, ed.), pp. 158-176, Tokyo: Oxford University Press.

CRONER, C. M.; SPERLING, J. \& BROOME, F. R., 1996. Geographic Information Systems (GIS): New perspectives in understanding human health and environmental relationships. Statistics in Medicine, 15:1961-1977.

DIEZ-ROUX, A. V., 1998. Bringing context back into epidemiology: Variables and multilevel analysis. American Journal of Public Health, 88:216-222.

GESLER, W. M.; BIRD, S. T. \& OLJESKI, A. S., 1997. Disease ecology and a reformist alternative: The case of infant mortality. Social Science and Medicine, 44:657-671.

HELLER, L., 1997. Saneamento e Saúde. Brasília: Organização Panamericana da Saúde.

IBGE, 2000. SIDRA - Sistema IBGE de Recuperação Automática. March $2000<$ http://www.sidra.ibge. gov.br>.

IPLANRIO (Empresa Municipal de Informática e Planejamento), 1995. Anuário Estatístico da Cidade do Rio de Janeiro. Rio de Janeiro: IPLANRIO.

KATZ, A. R.; MANEA, S. J. \& SASAKI, D. M., 1991. Leptospirosis on Kauai: Investigation of a common source of waterborne outbreak. American Journal of Public Health, 81:1310-1312.

KO, A. I.; GALVÃO-REIS, M.; RIBEIRO-DOURADO, C. M.; JOHNSON, W. D. \& RILEY, L. W., 1999. Urban epidemic of severe leptospirosis in Brazil. Lancet, 354:820-825.
KOLSKY, P. J. \& BLUMENTHAL, U. J., 1995. Environmental health indicators and sanitation-related disease in developing countries: Limitations to the use of routine data. World Health Statistics Quarterly, 48:132-139.

LACAZ, C. S.; BARUZZI, R. G. \& SIQUEIRA Jr., W., 1972. Introdução à Geografia Médica do Brasil. São Paulo: Editora Edgard Blucher.

NURMINEN, M., 1995. Linkage failures in ecological studies. World Health Statistics Quarterly, 48:7884.

PAVLOWSKY, E., 1988. Natural nidality of transmissible diseases in relation to landscape epidemiology of zooanthroponoeses. In: The Challenge of Epidemiology. PAHO Scientific Publication No. 505, pp. 401-405, Washington, D.C.: Pan American Health Organization.

PEREIRA, M. M. \& ANDRADE, J., 1988. Epidemiological aspects of leptospirosis in a slum area in the city of Rio de Janeiro, Brazil. Search for leptospirosis and specific antibodies in rodents. Transactions of the Royal Society of Tropical Medicine and Hygiene, 82:768-770.

PEREIRA, M. M. \& ANDRADE, J., 1990. Human leptospirosis in a slum area in the city of Rio de Janeiro, Brazil - A serological and epidemiological study. Memórias do Instituto Oswaldo Cruz, 85:47-52.

PHILIPPI Jr., A., 1988. Saneamento do Meio. São Paulo: Editora Fundacentro.

SANTOS, M., 1996. Técnica, Espaço, Tempo. São Paulo: Editora Hucitec.

SEXTON, K.; WAGENER, D. K. \& LYBARGER, J. A., 1992. Estimating human exposures to environmental pollutants: Availability and utility of existing databases. Archives of Environmental Health, 47:398-407.

SMS (Secretaria Municipal de Saúde), 1997. Série Histórica da Leptospirose no Rio de Janeiro. Rio de Janeiro: Superintendência de Saúde Coletiva, Secretaria Municipal de Saúde.

VELAZQUEZ, J. Z.; CANTARELL, K. P.; CASTILLO, M. F. \& CENTENO, A. G. D., 1984. La leptospirosis en Yucatán. Estudio serológico en humanos y animales. Salud Pública de México, 26:254-259.

VINE, M. F.; DEGNAN, D. \& HANCHETTE, C., 1997. Geographic information systems: Their use in environmental epidemiologic research. Environmental Health Perspectives, 105:598-605.

WILLIAMS, B. T., 1990. Assessing the health impact of urbanization. World Health Statistics Quarterly, 43:145-152. 